Anita Febrianingtyas, Purwanta, Heru Subekti

Hubungan Antara Tugas Kesehatan Keluarga Dalam Modifikasi Lingkungan Rumah Dengan Kejadian

Penularan Tuberkulosis

\title{
Hubungan Antara Tugas Kesehatan Keluarga Dalam Modifikasi Lingkungan Rumah Dengan Kejadian Penularan Tuberkulosis
}

\author{
Anita Febrianingtyas ${ }^{1}$, Purwanta $^{2}$, Heru Subekti $^{3}$ \\ ${ }^{1}$ Program Studi Sarjana Keperawatan Fakultas Kedokteran Universitas Gadjah Mada \\ ${ }^{2,3}$ Program Studi Ilmu Keperawatan Fakultas Kedokteran Universitas Gadjah Mada
}

\begin{abstract}
Abstrak
Penyakit TBC merupakan penyebab pertama pada kelompok penyakit infeksi dalam waktu satu tahun satu orang penderita dapat menularkan kepada 10-15 orang sekelilingnya.Peran keluarga sangat penting dalam pengobatan penderita TBC,selain memberikan dukungan dalam pengobatan, keluarga juga berperan dalam menciptakan rumah yang sehat, sehingga penularan TBC dapat dicegah. Tujuan dari penelitian ini adalah untuk mengetahui hubungan antara tugas kesehatan keluarga dalam modifikasi lingkungan rumah dengan kejadian penularan TBC di Puskesmas Kota Jogja. Penelitian ini merupakan jenis penelitian analitik korelasional dan menggunakan metode kuantitatif dengan rancangan penelitian cross sectional. Menggunakan teknik purposive sampling, responden didapatkan sebanyak 27 orang dari 6 Puskesmas di Kota Jogja. Data diambil Juli sampai Agustus 2015. Analisis data menggunakan metode Fisher Exact. Dari total 27 responden terjadi penularan serumah sebanyak 4 orang atau sebesar 14,8\% sedangkan dari 23 (85,2\%) penderita TBC tidak terjadi penularan. Hasil uji Fisher Exact pada setiap aspek kesehatan rumah menunjukkan nilai $p>0,05$. Tidak terdapat hubungan antara pelaksanaan tugas kesehatan keluarga dalam modifikasi lingkungan rumah dengan kejadian penularan tuberkulosis di Puskesmas Kota Jogja.
\end{abstract}

Kata kunci: tugas kesehatan keluarga; modifikasi lingkungan rumah; tuberkulosis

\section{PENDAHULUAN}

Mycobacterium tuberkulosis
telah menginfeksi penduduk dunia. Pada tahun 1993, World Health Organization (WHO) mencanangkan kedaruratan global penyakit Tuberkulosis (TBC) karena pada sebagian besar negara di dunia penyakit TBC tidak terkendali. Ini disebabkan banyaknya penderita yang tidak berhasil disembuhkan, terutama penderita menular (BTA positif) (Depkes RI, 2003). Terdapat 2,9 juta kasus TBC pada tahun 2012 dengan jumlah kematian karena TBC mencapai 410.000 kasus termasuk di antaranya adalah 160.000 orang wanita dengan HIV positif. Separuh dari orang dengan HIV positif yang meninggal karena TBC pada 2012 adalah wanita. Diperkirakan juga terdapat 450.000 orang yang menderita Multi Drugs Resistence (MDR) dan 170.000 di antaranya meninggal dunia (Dirjen P2PL, 2014).

Lingkungan yang paling dekat dengan manusia adalah rumah, sebab pada umumnya manusia menghabiskan waktunya di dalam rumah. Rumah sebagai tempat tinggal harus senantiasa diperhatikan aspek kesehatannya, agar dapat tercipta suatu kondisi rumah yang layak huni dalam lingkungan yang sehat, sehingga mampu mengurangi 
Anita Febrianingtyas, Purwanta, Heru Subekti

Hubungan Antara Tugas Kesehatan Keluarga Dalam Modifikasi Lingkungan Rumah Dengan Kejadian

Penularan Tuberkulosis

risiko penularan penyakit menular yang membahayakan manusia. Salah satu contoh bibit penyakit menular yang berada di udara yaitu basil Mycobacterium Tuberculosis yang dapat menyebabkan penyakit Tuberculosis paru, oleh karena itu sanitasi rumah harus selalu diperhatikan diantaranya terdapat pencahayaan yang diperoleh dari sinar matahari yang masuk melalui jendela, mulai dari pagi hingga siang. Sifat dari basil Tuberculosis ini apabila di luar tubuh manusia, terutama di tempat sejuk, lembab, gelap basil ini dapat hidup bertahuntahun lamanya. Tetapi basil ini akan mati jika terkena sinar matahari, sabun, lisol, karbon dan panas api. Infeksi primer terjadi pada individu yang sebelumnya belum memiliki kekebalan tubuh (Danudoyo, 2007).

Keluarga berfungsi untuk melaksanakan praktek asuhan kesehatan, yaitu mencegah terjadinya gangguan kesehatan dan/atau merawat anggota keluarga yang sakit. Kemampuan keluarga dalam memberikan asuhan kesehatan mempengaruhi status kesehatan keluarga. Kesanggupan keluarga melaksanakan pemeliharaan kesehatan dapat dilihat dari tugas kesehatan keluarga yang dilaksanakan. Keluarga dapat melaksanakan tugas kesehatan berarti sanggup menyelesaikan masalah kesehatan keluarga.

Tugas kesehatan keluarga menurut Friedman (2004) antara lain : mengenal masalah kesehatan keluarga, membuat keputusan tindakan keperawatan yang tepat, memberi perawatan pada anggota keluarga yang sakit, mempertahankan suasana rumah yang sehat, menggunakan fasilitas kesehatan yang ada di masyarakat.

\section{METODE}

Penelitian ini merupakan jenis penelitian analitik korelasional dan menggunakan metode kuantitatif dengan rancangan penelitian cross sectional. yang dilaksanakan pada Juli - Agustus 2015. Metode pemilihan sampel yang digunakan adalah purposive sampling (Setiadi, 2007). Sampel diambil dari enam (6) Puskesmas dengan jumlah penderita TBC terbanyak yaitu Puskesmas Jetis sebanyak 7 orang, Puskesmas Gondokusuman II sebanyak 6 orang, Puskesmas Umbulharjo II sebanyak 5 orang, Puskesmas Wirobrajan sebanyak 6 orang, Puskesmas Mergangsan sebanyak 5 orang, dan Puskesmas Kotagede II sebanyak 7 orang.

\section{HASIL}

Pada tabel 1 (terlampir) dapat diketahui bahwa jumlah responden terbanyak adalah perempuan yaitu 18 orang $(66,7 \%)$. Responden sebagian besar berada pada rentang usia 31 50 tahun yaitu sebanyak 11 orang $(41,0 \%)$. Dari tabel tersebut dapat diketahui jumlah responden laki-laki sebanyak 8 orang $(33,3 \%)$ dan perempuan sebanyak 18 orang $(66,7 \%)$.

Dari hasil penelitian didapatkan hasil penderita $\mathrm{Tb}$ sebanyak 27 orang, terdiri dari 13 orang $(48,1 \%)$ laki-laki dan 14 orang perempuan atau sebesar $(51,95 \%)$. Jumlah penderita TB dengan umur kurang dari 30 tahun sebanyak 5 orang $(18,6 \%)$, umur antara 31 sampai 40 tahun sebanyak 7 orang $(25,9 \%)$, umur antara 41 hingga 50 
Anita Febrianingtyas, Purwanta, Heru Subekti

Hubungan Antara Tugas Kesehatan Keluarga Dalam Modifikasi Lingkungan Rumah Dengan Kejadian

Penularan Tuberkulosis

tahun sebanyak 6 orang $(22,2 \%)$, umur antaran51 hingga 60 tahun sebanyak 6 orang $(22,2 \%)$, dan usia di atas 60 tahun sebanyak 3 orang $(11,1 \%)$.

Pencahayaan kamar penderita $\mathrm{Tb}$ yang baik adalah sejumlah 19 rumah atau sebesar $70,4 \%$ dengan kejadian penularan sebanyak dua orang, sedangkan pencahayaan yang tidak baik adalah sejumlah 8 rumah atau sebesar $29,6 \%$ dengan kejadian penularan sebanyak 2 orang. Nilai signifikansi yang didapat adalah 0,558 sehingga karena nilai $\mathrm{p}>0,05$ maka secara statistik tidak terdapat hubungan antara cahaya ruangan kamar penderita dengan kejadian penularan $\mathrm{Tb}$.

Pencahayaan ruangan rumah yang baik sebesar 7 rumah atau $25,9 \%$ dengan kejadian penularan sebanyak satu (1) orang dan jumlah rumah dengan pencahayaan ruangan tidak baik adalah sejumlah 20 rumah $(74,1 \%)$ dengan kejadian penularan sebesar 3 orang. Nilai $\mathrm{p}$ adalah sebesar 1,000, sehingga dapat disimpulkan bahwa tidak ada hubungan antara pencahayaan ruangan rumah dengan kejadian penularan $\mathrm{Tb}$.

Dari hasil penelitian diperoleh data jumlah rumah dengan ventilasi kamar penderita yang baik adalah sejumlah 9 rumah saja atau sebesar $33,3 \%$, terdapat penularan serumah sebanyak satu (satu) orang. Jumlah rumah dengan keadaan ventilasi kamar tidak memenuhi syarat yaitu sebanyak 18 rumah atau sebesar $66,7 \%$, terjadi penularan serumah sebanyak 3 kasus. Nilai signifikansi menunjukkan sebesar 1,000 yang berarti tidak ada hubungan antara ventilasi kamar penderita dengan kejadian penularan TBC.

Banyaknya rumah dengan ventilasi ruangan yang memenuhi syarat sebanyak delapan (8) rumah atau sebesar 29,6\% di mana terjadi kasus penularan serumah sebanyak satu (1) orang. Rumah dengan ventilasi yang tidak memenuhi syarat adalah sejumlah 19 rumah $(70,4 \%)$ dengan kejadian penularan serumah sebanyak tiga (3) orang. Nilai p lebih besar dari 0,05 yaitu sebesar 1,000 menunjukkan bahwa tidak terdapat hubungan antara ventilasi ruangan dengan kejadian penularan TBC.

Keadaan lantai rumah yang memenuhi syarat adalah sebanyak 21 rumah $(77,8 \%)$ di mana terjadi penularan serumah sebanyak 2 orang, sedangkan lantai rumah yang tidak memenuhi syarat sebanyak 6 rumah atau sebesar 22,2\%. Kejadian penularan serumah pada rumah dengan keadaan lantai tidak memenuhi syarat adalah sebanyak 2 kasus. Nilai signifikansi yang didapat adalah 0,204 yang menunjukkan tidak ada hubungan antara keadaan lantai rumah dengan kejadian penularan $\mathrm{Tb}$.

Dari penelitian yang dilakukan diperoleh hasil banyaknya rumah dengan kelembaban kamar yang baik adalah sebanyak 26 rumah atau prosentase sebesar 96,3\%. Kejadian penularan sebanyak empat (4) orang. Namun sebaliknya, kelembaban kamar yang tidak baik hanya sejumlah 1 rumah $(3,7 \%)$ dan tidak terdapat kasus penularan sama sekali. Nilai p yang diperoleh adalah sebesar 1,000 sehingga dapat disimpulkan bahwa tidak terdapat hubungan antara kelembaban kamar penderita 
Anita Febrianingtyas, Purwanta, Heru Subekti

Hubungan Antara Tugas Kesehatan Keluarga Dalam Modifikasi Lingkungan Rumah Dengan Kejadian Penularan Tuberkulosis

$\mathrm{Tb}$ dengan kejadian penularan serumah.

Banyaknya rumah dengan kelembaban ruangan yang memenuhi syarat adalah sebanyak 25 rumah atau sebesar $92,6 \%$ dan terdapat kejadian penularan sebanyak empat (4) orang. Sebaliknya, banyaknya rumah dengan kelembaban ruangan tidak memenuhi syarat hanya sebanyak 2 rumah namun sama sekali tidak terjadi kejadian penularan. Nilai signifikansi yang diperoleh adalah sebesar 1,000 menunjukkan tidak ada hubungan antara kelembaban ruangan rumah dengan kejadian penularan TBC.

Keadaan dinding rumah yang memenuhi syarat yaitu sebanyak 21 rumah $(77,8 \%)$ dengan kejadian penularan serumah sebanyak 4 orang. Sebaliknya, keadaan dinding rumah yang tidak memenuhi syarat adalah sebanyak 6 rumah $(22,2 \%)$ namun tidak terdapat kejadian penularan serumah. Nilai $\mathrm{p}$ yang didapat adalah sebesar 0,545 yang menunjukkan tidak ada hubungan antara keadaan dinding rumah dengan kejadian penularan TBC.

Dari hasil penelitian dapat diketahui jumlah rumah dengan keadaan atap rumah memenuhi syarat sebanyak lima (5) rumah atau hanya sebesar $18,5 \%$ saja. Tidak terjadi penularan serumah pada rumah dengan keadaan atap rumah yang memenuhi syarat. Rumah dengan keadaan atap tidak memenuhi syarat sebanyak 22 rumah $(81,5 \%)$ dan terjadi penularn serumah sebanyak 4 kasus. Nilai signifikansi yang diperoleh sebesar 0,561 yang berarti tidak ada hubungan antara keadaan atap rumah dengan kejadian penularan $\mathrm{Tb}$.
Keadaan tempat tidur penderita yang memenuhi syarat yaitu sebanyak 15 rumah $(55,6 \%)$ dan terjadi penularan sebanyak 2 orang. Sedangkan tempat tidur penderita yang tidak memenuhi syarat adalah sebanyak 12 responden $(44,4 \%)$ dan terjadi kejadian penularan sebanyak 2 kasus. Nilai $p$ yang diperoleh adalah sebesar 1,000 yang menunjukkan tidak ada hubungan antara keadaan tempat tidur penderita dengan kejadian penularan TBC.

Dari hasil penelitian diperoleh jumlah rumah dengan kepadatan penghuni memenuhi syarat sebanyak 14 rumah atau sebesar 51,9\% dengan kejadian penularan sebanyak 2 orang. Jumlah rumah dengan kepadatan penghuni yang tidak memenuhi syarat adalah sejumlah 13 rumah $(48,1 \%)$ dengan kejadian penularan sebanyak dua (2) orang. Nilai signifikansi yang diperoleh adalah sebesar 1,000 yang berarti tidak ada hubungan antara kepadatan penghuni dengan kejadian penularan TBC.

Diketahui sebanyak 18 anggota keluarga melakukan pemisahan alat makan penderita atau prosentase sebesar 66,7\%. Dari 18 rumah tersebut tetap terjadi penularan $\mathrm{Tb}$ sebanyak tiga (3) orang. Sedangkan, responden yang tidak memisahkan alat makan penderita sebanyak sembilan (9) orang atau sebesar $33,3 \%$ dan terjadi kasus penularan sebanyak satu (1) orang. Nilai p menunjukkan sebesar 1,000 yang berarti tidak terdapat hubungan antara pemisahan alat makan dengan kejadian penularan TBC. 
Anita Febrianingtyas, Purwanta, Heru Subekti

Hubungan Antara Tugas Kesehatan Keluarga Dalam Modifikasi Lingkungan Rumah Dengan Kejadian

Penularan Tuberkulosis

Tabel 1. Distribusi Frekuensi Karakteristik Keluarga Penderita TBC Puskesmas Kota Jogja $(n=27)$

\begin{tabular}{llcc}
\hline \multicolumn{1}{c}{ Variabel } & & $\mathrm{n}$ & $\%$ \\
\hline Jenis kelamin & Laki-laki & 9 & 33,3 \\
\cline { 2 - 4 } & Perempuan & 18 & 66,7 \\
\hline \multirow{2}{*}{ Umur } & $15-30$ tahun & 10 & 37,0 \\
\cline { 2 - 4 } & $31-50$ tahun & 11 & 41,0 \\
\cline { 2 - 4 } & $51-70$ tahun & 6 & 22,0 \\
\hline Hubungan dengan penderita & Suami & 1 & 3,7 \\
\cline { 2 - 4 } & Istri & 6 & 29,7 \\
\cline { 2 - 4 } & Anak & 2 & 7,4 \\
\cline { 2 - 4 } & Menantu & 5 & 18,6 \\
\cline { 2 - 4 } & Kakak/adik & 5 & 18,6 \\
\cline { 2 - 4 } & Keponakan & & \\
\hline
\end{tabular}

Sumber: data primer, 2015

Tabel 2. Distribusi Frekuensi Karakteristik Penderita Tb Puskesmas Kota Jogja $(n=27)$

\begin{tabular}{|c|c|c|c|}
\hline Variabel & & $\mathrm{n}$ & $\%$ \\
\hline \multirow[t]{2}{*}{ Jenis kelamin } & Laki-laki & 13 & 48,1 \\
\hline & Perempuan & 14 & 51,9 \\
\hline \multirow[t]{5}{*}{ Umur } & $<30$ tahun & 5 & 18,6 \\
\hline & 31-40 tahun & 7 & 25,9 \\
\hline & 41-50 tahun & 6 & 22,2 \\
\hline & 51-60 tahun & 6 & 22,2 \\
\hline & $>60$ tahun & 3 & 11,1 \\
\hline \multirow[t]{6}{*}{ Pendidikan } & SD & 4 & 14,8 \\
\hline & SMP & 6 & 22,2 \\
\hline & SMA & 8 & 29,6 \\
\hline & D3/S1 & 7 & 25,9 \\
\hline & $\mathrm{S} 2$ & 1 & 3,7 \\
\hline & Tidak sekolah & 1 & 3,7 \\
\hline \multirow{7}{*}{ Pekerjaan } & PNS & 1 & 3,7 \\
\hline & Karyawan swasta & 5 & 18,5 \\
\hline & Buruh & 3 & 11,1 \\
\hline & Guru & 2 & 7,4 \\
\hline & Pedagang & 2 & 7,4 \\
\hline & Ibu rumah tangga & 2 & 7,4 \\
\hline & Lain-lain & 8 & 29,6 \\
\hline
\end{tabular}

Sumber: data primer, 2015 
Anita Febrianingtyas, Purwanta, Heru Subekti

Hubungan Antara Tugas Kesehatan Keluarga Dalam Modifikasi Lingkungan Rumah Dengan Kejadian

Penularan Tuberkulosis

Tabel 3. Analisa Hubungan antara Cahaya Ruangan Kamar Penderita dengan Penularan TBC

\begin{tabular}{|c|c|c|c|c|c|}
\hline & \multicolumn{2}{|c|}{ Penularan $\mathrm{Tb}$} & \multirow[t]{2}{*}{$\sum$} & \multirow[t]{2}{*}{$\mathrm{p}$} \\
\hline & & $\mathrm{Ya}$ & Tidak & & \\
\hline \multirow{2}{*}{$\begin{array}{l}\text { Pencahayaan } \\
\text { Kamar Penderita }\end{array}$} & Baik & 2 & 6 & 8 & \multirow{3}{*}{0,558} \\
\hline & Tidak baik & 2 & 17 & 19 & \\
\hline Total & & 4 & 23 & 27 & \\
\hline
\end{tabular}

Sumber : Data Primer, 2015

Tabel 4. Analisa Hubungan antara Cahaya Ruangan Rumah dengan Penularan TBC

Penularan $\mathrm{Tb} \quad \sum \quad \mathrm{p}$

\begin{tabular}{|c|c|c|c|c|}
\hline & & $\mathrm{Ya}$ & Tidak & \\
\hline $\begin{array}{l}\text { Pencahayaan } \\
\text { Rumah }\end{array}$ & Ruangan Baik & 1 & 6 & 8 \\
\hline
\end{tabular}

\begin{tabular}{lllll} 
& Tidak baik & 3 & 17 & 20 \\
\hline Total & & 4 & 23 & 27
\end{tabular}

Sumber : Data Primer, 2015

Tabel 5. Analisa Hubungan antara Ventilasi Kamar Penderita Tb dengan Penularan TBC

Penularan $\mathrm{Tb} \quad \sum \quad \mathrm{p}$

\begin{tabular}{|c|c|c|c|c|}
\hline & & $\mathrm{Ya}$ & Tidak & \\
\hline Ventilasi & Kamar Baik & 1 & 8 & 9 \\
\hline
\end{tabular}

\begin{tabular}{lllll} 
& Tidak baik & 3 & 15 & 18 \\
\hline Total & & 4 & 23 & 27
\end{tabular}

Sumber : Data Primer, 2015 
Anita Febrianingtyas, Purwanta, Heru Subekti

Hubungan Antara Tugas Kesehatan Keluarga Dalam Modifikasi Lingkungan Rumah Dengan Kejadian Penularan Tuberkulosis

Tabel 6. Analisa Hubungan antara Ventilasi Ruangan dengan Penularan TBC

Penularan $\mathrm{Tb} \quad \sum \quad \mathrm{p}$

\begin{tabular}{|c|c|c|c|c|c|}
\hline & & $\mathrm{Ya}$ & Tidak & & \\
\hline \multirow[t]{2}{*}{ Ventilasi Ruangan } & Baik & 1 & 7 & 8 & \multirow{3}{*}{1,000} \\
\hline & Tidak baik & 3 & 16 & 19 & \\
\hline Total & & 4 & 23 & 27 & \\
\hline
\end{tabular}

Sumber : Data Primer, 2015

Tabel 7. Analisa Hubungan antara Keadaan Lantai Rumah dengan Penularan TBC

Penularan $\mathrm{Tb} \quad \mathrm{p}$

\begin{tabular}{|c|c|c|c|}
\hline & $\mathrm{Ya}$ & Tidak & \\
\hline Keadaan Lantai Rumah Baik & 2 & 19 & 21 \\
\hline
\end{tabular}

\begin{tabular}{lllll} 
& Tidak baik & 2 & 4 & 6 \\
\hline Total & & 4 & 23 & 27
\end{tabular}

Sumber : Data Primer, 2015

Tabel 8. Analisa Hubungan antara Kelembaban Kamar Penderita TBC dengan Penularan TBC

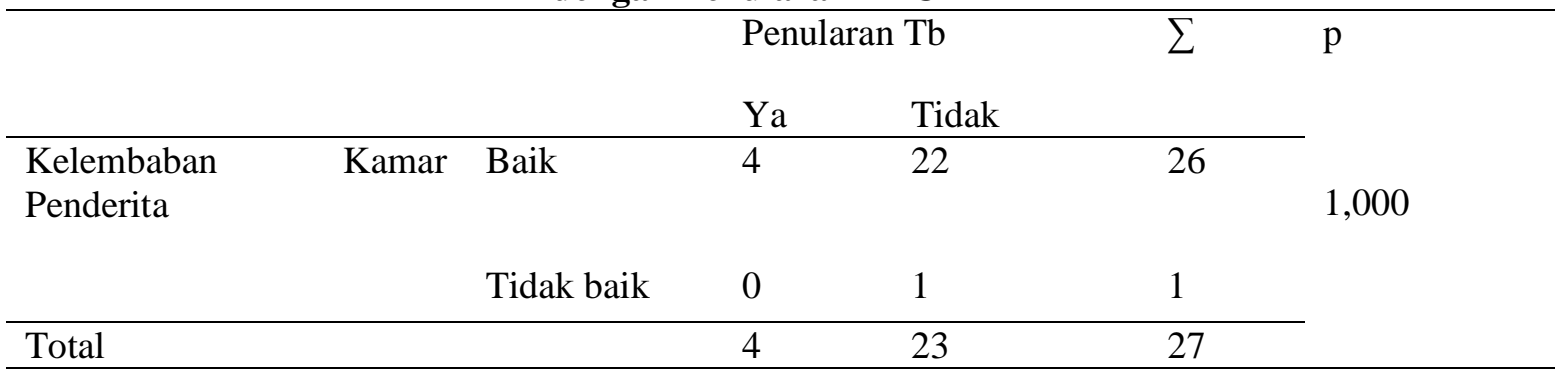

Sumber : Data Primer, 2015

Tabel 9. Analisa Hubungan antara Kelembaban Ruangan dengan Penularan TBC

\begin{tabular}{llllll}
\hline & & \multicolumn{2}{c}{ Penularan Tb } & $\sum$ & $\mathrm{p}$ \\
& & Ya & Tidak & \\
\cline { 1 - 4 } Kelembaban Ruangan & Baik & 4 & 21 & 25 & \multirow{2}{*}{1,000} \\
& Tidak baik & 0 & 2 & 2 & \\
\cline { 1 - 4 } & & 4 & 23 & 27 &
\end{tabular}

Sumber : Data Primer, 2015 
Anita Febrianingtyas, Purwanta, Heru Subekti

Hubungan Antara Tugas Kesehatan Keluarga Dalam Modifikasi Lingkungan Rumah Dengan Kejadian Penularan Tuberkulosis

Tabel 10. Analisa Hubungan antara Keadaan Dinding Rumah dengan Penularan TBC

\begin{tabular}{|c|c|c|c|c|c|c|}
\hline & & & \multicolumn{2}{|c|}{ Penularan $\mathrm{Tb}$} & \multirow[t]{2}{*}{$\sum$} & \multirow[t]{2}{*}{$\mathrm{p}$} \\
\hline & & & $\mathrm{Ya}$ & Tidak & & \\
\hline $\begin{array}{l}\text { Keadaan } \\
\text { Rumah }\end{array}$ & Dinding & Baik & 4 & 17 & 21 & \multirow[t]{3}{*}{0,545} \\
\hline & & Tidak baik & 0 & 6 & 6 & \\
\hline Total & & & 4 & 23 & 27 & \\
\hline
\end{tabular}

Sumber : Data Primer, 2015

Tabel 11. Analisa Hubungan antara Keadaan Atap Rumah dengan Penularan TBC

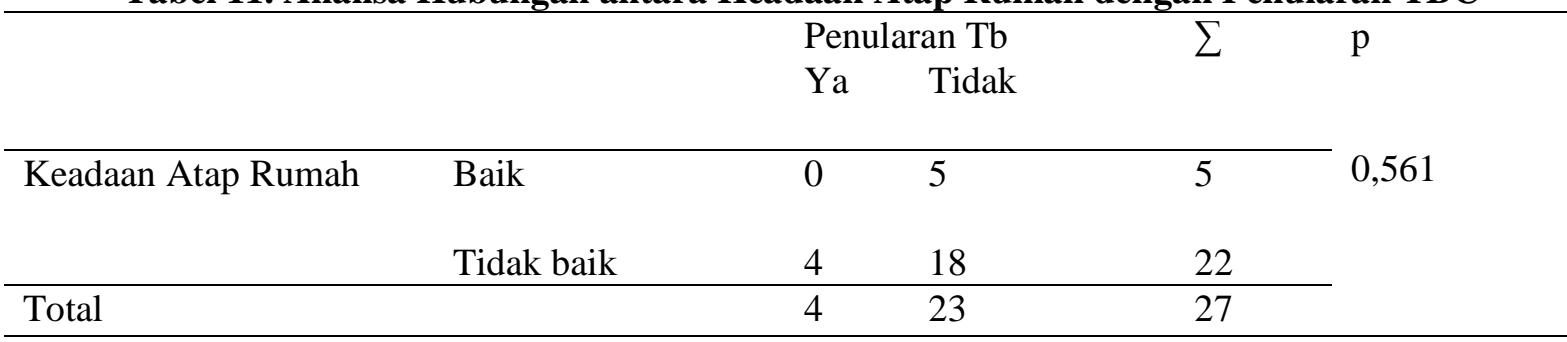

Sumber : Data Primer, 2015

Tabel 12. Analisa Hubungan antara Keadaan Tempat Tidur Penderita dengan Penularan TBC

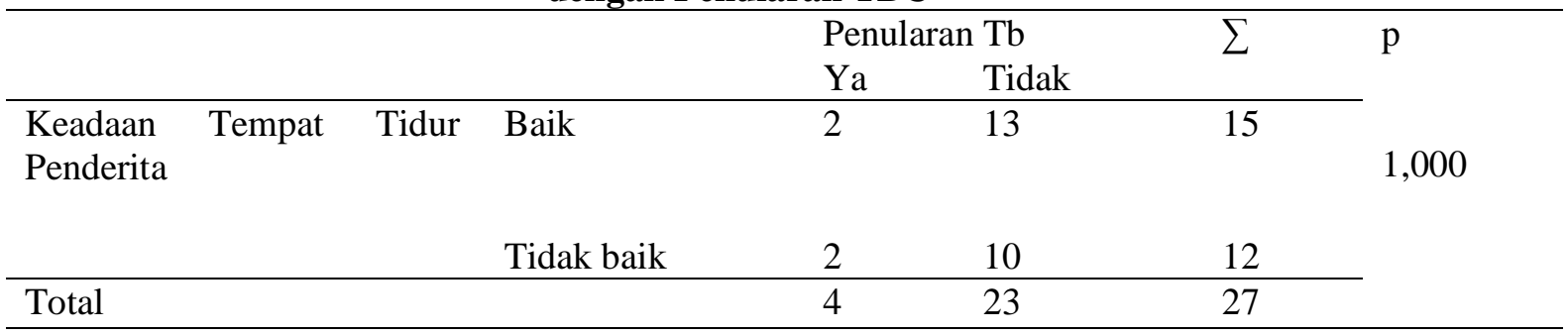

Sumber : Data Primer, 2015

Tabel 13. Analisa Hubungan antara Kepadatan Penghuni dengan Penularan TBC

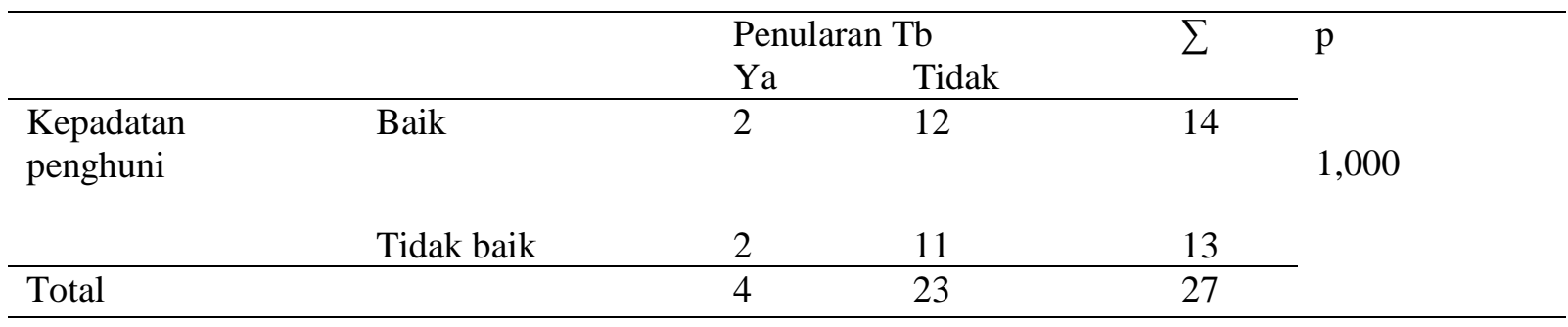

Sumber : Data Primer, 2015 
Anita Febrianingtyas, Purwanta, Heru Subekti

Hubungan Antara Tugas Kesehatan Keluarga Dalam Modifikasi Lingkungan Rumah Dengan Kejadian

Penularan Tuberkulosis

Tabel 14. Analisa Hubungan antara Pemisahan Alat Makan dengan Penularan TBC

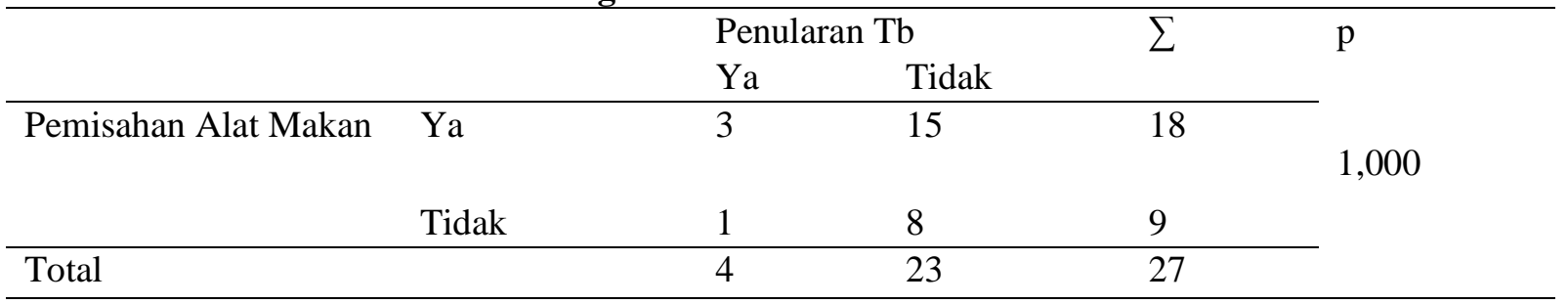

Sumber : Data Primer, 2015

\section{PEMBAHASAN}

Pada penelitian yang telah dilakukan didapatkan hasil bahwa tidak ada hubungan yang bermakna antara pelaksanaan tugas kesehatan keluarga dengan pencahayaan kamar, pencahayaan ruangan, kelembaban kamar, kelembaban ruangan, ventilasi kamar, ventilasi ruangan, keadaan lantai, keadaan atap, keadaan dinding, keadaan tempat tidur penderita, kepadatan penghuni, dan pemisahan alat makan dengan kejadian penularan TBC. Dari total 27 responden terjadi penularan serumah sebanyak 4 orang atau sebesar 14,8\% sedangkan dari 23 penderita TBC tidak terjadi penularan.

Hal ini tidak sesuai dengan penelitian Wajdi (2005) tentang "Kesehatan Lingkungan Rumah dan Kejadian Penularan Tuberkulosis Paru di Kabupaten Agam Sumatera Barat", yang menyatakan bahwa ada hubungan yang bermakna (signifikan) antara kesehatan lingkungan rumah, status gizi, dan sumber penularan dengan kejadian penyakit TB paru (BTA positif). Selain itu, ada hubungan negatif antara kesehatan lingkungan rumah dan status gizi dengan kejadian penyakit paru. Ada hubungan positif antara sumber penularan dengan kejadian penyakit TB paru, artinya semakin banyak sumber penularan yang tinggal serumah, semakin besar risiko tertular penyakit TB paru. Sub variabel kesehatan lingkungan rumah yang sumbangannya terhadap kejadian TB paru berdasarkan urutan yang terbesar adalah: kelembaban kamar tidur, kelembaban rumah, ventilasi kamar tidur, ventilasi rumah, kuat cahaya alami yang masuk ke dalam kamar tidur, kuat cahaya alami yang masuk ke dalam rumah, dan kepadatan hunian kamar tidur. Perbedaan yang terjadi dimungkinkan terjadi karena faktor lain yang berupa status gizi dan juga perbedaan sumber penularan dari luar rumah.

Hasil penelitian ini juga berbeda dengan penelitian Nevita (2013) tentang "Faktor Resiko Kejadian Sakit Tuberkulosis pada Anak yang Kontak Serumah dengan Penderita Tuberkulosis Dewasa di Kabupaten Barito Kuala" yang menunjukkan luas ventilasi dan pencahayaan rumah berhubungan secara signifikan dengan kejadian TBC paru dewasa.

Kepadatan hunian,kelembaban,kondisi lantai, dan jenis dinding tdk berhubungan secara signifikan. Kesimpulan dari penelitian tersebut adalah faktor pencahayaan rumah sangat dominan.

Tidak adanya hubungan antar variabel dalam penelitian ini dimungkinkan terdapat faktor - faktor resiko lain yang menyebabkan penularan Tb. Faktor risiko lainnya adalah malnutrisi, keadaan imunokompromis (misalnya pada infeksi HIV, keganasan, transplantasi 
Anita Febrianingtyas, Purwanta, Heru Subekti

Hubungan Antara Tugas Kesehatan Keluarga Dalam Modifikasi Lingkungan Rumah Dengan Kejadian

Penularan Tuberkulosis

organ dan pengobatan imunosupresi), diabetes mellitus dan gagal ginjal kronik (Kartasaswita \& Basir, 2008), kondisi tempat tinggal yang padat, derajat keparahan kasus penular yang dilhat dari pemeriksaan sputum basil tahan asam (BTA) positif, kelainan pada paru secara radiologis, dan ibu sebagai penular (Kenyon, Creek, Laserson et al, 2002).

Peluang peningkatan paparan terkait dengan jumlah kasus menular di masyarakat, peluang kontak dengan kasus menular, tingkat daya tular dahak sumber penularan, intensitas batuk sumber penularan, kedekatan kontak dengan sumber penularan, lamanya waktu kontak dengan sumber penularan, faktor lingkungan yang antara lain konsentrasi kuman diudara (ventilasi, sinar ultra violet, penyaringan adalah faktor yang dapat menurunkan konsentrasi (Depkes RI, 2014).

Dari hasil penelitian yang merupakan hasil observasi dan pengukuran cahaya ruangan rumah dengan luxmeter, jumlah rumah dengan cahaya ruangan kurang dari 60 lux adalah 15 rumah $(55,5 \%)$, rumah dengan cahaya ruangan antara $60-120$ lux sebanyak 8 rumah atau sebesar $29,7 \%$, dan rumah dengan cahaya ruangan di atas 120 lux sebanyak 4 rumah atau sebesar $14,8 \%$. Observasi cahaya kamar penderita TBC menunjukkan kamar penderita yang mempunyai cahaya kurang dari 60 lux adalah sebanyak 25 rumah (92,6\%), sedangkan yang mememenuhi standar kesehatan antara 60 sampai dengan 120 hanya 2 rumah saja atau sebesar 7,4\%. Dari empat (4) kasus penularan serumah didapatkan hasil observasi cahaya ruangan rumah 55 lux, 240 lux, 90 lux, dan 10 lux. Hasil ini sangat bervariasi dari cahaya ruangan yang sangat minim hingga berlebih.

Berdasar observasi, rumah penderita TBC dengan jendela kamar penderita selalu dibuka sebanyak 16 rumah $(59,3 \%)$, tidak dibuka sebanyak 11 rumah (40,7\%). Jumlah rumah dengan jendela selalu dibuka sebanyak 16 rumah (40,7\%), tidak dibuka sebanyak 16 rumah atau sebesar 59,3\%. Resiko terkena TBC 5,2 kali pada penghuni yang memiliki ventilasi buruk dibanding penduduk yang tinggal di rumah berventilasi memenuhi syarat kesehatan (Achmadi, 2005).

\section{KESIMPULAN}

Tidak terdapat hubungan antara pelaksanaan tugas kesehatan keluarga dalam modifikasi lingkungan rumah dengan kejadian penularan tuberkulosis di Puskesmas Kota Jogja.

\section{DAFTAR PUSTAKA}

Depkes RI. (2003). Pedoman Nasional Penanggulangan Tuberkulosis Cetakan ke-8. Jakarta: Depkes RI.

Dirjen P2PL. (2014). Profill PP dan PL Tahun 2014 [serial online] [disitasi pada tanggal 10 Agustus 2015]. Diakses dari URL : http://www.pppl.depkes.go.id.

Danudoyo. (2007). Masih 10 Persen Masyarakat Indonesia Menderita TBC [serial online] [disitasi pada tanggal 10 Maret 2010]. Diak ses dari URL

http://kbi.gemari.or.id.

Friedman, M. (2004). Keperawatan Keluarga Edisi 3. Jakarta : EGC.

Setiadi. (2007). Konsep dan Penulisan Riset Keperawatan. Yogyakarta: Graha Ilmu.

Wajdi, H., Soebijanto, Iravati, S. (2005). Kesehatan Lingkungan Rumah dan Kejadian Penyakit 
Anita Febrianingtyas, Purwanta, Heru Subekti

Hubungan Antara Tugas Kesehatan Keluarga Dalam Modifikasi Lingkungan Rumah Dengan Kejadian

Penularan Tuberkulosis

Tuberkulosis Paru di Kabupaten Agam, Sumatera Barat. Jurnal Sains Kesehatan Vol.18, No.3, Juli 2005.

Nevita. (2013). Faktor Resiko Kejadian Sakit Tuberkulosis pada Anak yang Kontak Serumah dengan Penderita Tuberkulosis Dewasa. Tesis. Prodi Ilmu Kedokteran Klinik UGM.

Kartasasmita, CB., Basir, D. (2008). Tuberkulosis, Dalam: Rahajoe N, Supriyatno.

Kenyon, T.A., Creek, T., Laserson, K., et al. (2002). Risk factors for transmission of Mycobacterium tuberculosis from HIV-infected tuberculosis patients, Botswana: Int.J.Tuberc.Lung Dis. (6):843-50.

Depkes RI. (2014). Pedoman Nasional Penanggulangan Tuberkulosis. Jakarta: Depkes RI.

Achmadi,U.F. (2005). Manajemen Penyakit Berbasis Wilayah. Jakarta: Depkes. 